\title{
Production of extracellular polymeric substances (EPS) by benthic diatoms: effect of irradiance and temperature
}

\author{
Kirsten Wolfstein*, Lucas J. Stal \\ Netherlands Institute of Ecology (NIOO-KNAW), PO Box 140, 4400 AC Yerseke, The Netherlands
}

\begin{abstract}
An axenic culture of Cylindrotheca closterium and a natural community of benthic diatoms were used to study the effect of temperature and irradiance on the production of extracellular polymeric substances (EPS). In the culture, results depended on the growth stage of the algae and on whether absolute values or biomass-related values were considered. The highest amount of EPS (standing stock) was produced at 15 and $25^{\circ} \mathrm{C}$ during early stationary growth phase. When EPS concentrations were normalized to chlorophyll a ( $\mathrm{chl} \mathrm{a}$ ), maximum values were measured at 4 and $10^{\circ} \mathrm{C}$. Independent of temperature the ratios (EPS:chl a) decreased with increasing age of the culture. Additionally, differences between the investigated temperatures were less pronounced in older cultures. A field sample of benthic diatoms was used to study: (1) the combined effect of temperature and irradiance on primary production and excretion of EPS; and (2) the partitioning of photosynthetically fixed carbon (C) into different fractions of intracellular and extracellular $C$ pools by using a shortterm ${ }^{14} \mathrm{C}$ incorporation. Again highest values of primary production and EPS (production rates) were measured at $25^{\circ} \mathrm{C}$. At lower irradiances, the temperature of $35^{\circ} \mathrm{C}$ had an inhibitory effect on the production rates of all fractions. In the culture as well as in the natural sample, the fraction of EPS that was closely bound to the cells (attached EPS) and the soluble fraction (colloidal EPS) were produced in different amounts at the different temperatures. This suggested that the production of the 2 operationally defined fractions of EPS might serve different functions, e.g. for migration or for storage of reserve products.
\end{abstract}

KEY WORDS: Benthic diatoms · Cylindrotheca closterium $\cdot$ Extracellular polymeric substances $\cdot$ EPS $\cdot$ Irradiance $\cdot$ Temperature

\section{INTRODUCTION}

Coastal intertidal mudflats are often colonized by benthic microalgae. Epipelic diatoms form the most important part of this community. They produce highly hydrated, carbohydrate-rich exopolymeric substances (EPS) (Smith \& Underwood 1998). These substances play an important role in the ecosystem, besides being beneficial for the algae themselves (Hoagland et al.

${ }^{*}$ Present address: Institute for Inland Water Management and Waste Water Treatment (RIZA), PO Box 17, 8200 AA Lelystad, The Netherlands.

E-mail: k.wolfstein@riza.rws.minvenw.nl
1993). Both the diatoms and the EPS that they produce represent an important food source for bacteria and grazers (Decho 1990). The production of EPS is thought to increase the erosion threshold of the sediment (Paterson 1989). The effect of environmental parameters on the production of EPS, such as nutrients (Sutherland et al. 1998, Staats et al. 2000a) or irradiance (Smith \& Underwood 1998, Staats et al. 2000b), has been studied in some detail. Staats et al. (2000b) and Wolfstein et al. (unpubl.) demonstrated a direct relationship between the production of EPS and oxygenic photosynthesis. Furthermore, the dependence of microphytobenthic photosynthesis on light and temperature is known (Blanchard et al. 1998, Barranguet 
et al.). Hence, it can be assumed that not only irradiance, but also temperature must have an effect on the production of EPS. To our knowledge, the effect of temperature or the combined effect of different light intensities and temperature on EPS production in benthic diatoms has not been studied so far. This study aimed at the elucidation of the effect of temperature and light on the production of EPS by benthic diatoms. During the first experiment the effect of temperature on algal biomass and the amount of EPS (standing stock) at different growth phases was studied using an axenic culture of the benthic diatom Cylindrotheca closterium. A second, short-term incubation experiment was carried out with a field sample of a natural microphytobenthic community collected from the Westerschelde estuary (The Netherlands) in order to investigate the combined effects of temperature and irradiance on the production of EPS.

\section{MATERIALS AND METHODS}

Culture, growth conditions and sampling of the natural diatom population. In a first experiment, an axenic strain of Cylindrotheca closterium (Ehrenberg) was used to study the influence of temperature on the production of extracellular substances at different growth stages. Therefore, cells were grown at temperatures to which they are commonly exposed in the natural environment $\left(4,10,15,25\right.$ and $\left.35^{\circ} \mathrm{C}\right)$. The algae were cultured in $1 \mathrm{l}$ glass Erlenmeyer flasks filled with artificial seawater medium (Table 1) on a layer of purified seasand (Merck) that covered the bottom of the flasks. Incident photon irradiance was $100 \mu \mathrm{mol} \mathrm{m}^{-2} \mathrm{~s}^{-1}$ provided by Philips TLD 15W/840 fluorescent tubes on a 12:12 h light:dark cycle. Microscopic examination of subsamples of the culture which were stained by Sybergreen (Sigma) confirmed the absence of contaminating bacteria.

A second experiment was conducted with a natural sample of a mixed community of benthic diatoms in order to study the combined effects of temperature and irradiance on short-term production of extracellular substances. In this experiment, the partitioning of the photosynthetically fixed carbon (C) in different fractions of intra- and extracellular $\mathrm{C}$ was followed simultaneously. This was different from the first experiment, where only the content of extracellular substances was measured after a few days of growth at different temperatures. The natural population of benthic diatoms was sampled from the site 'Biezelingse Ham' at the Westerschelde, The Netherlands $\left(51^{\circ} 26^{\prime} 47^{\prime \prime} \mathrm{N}\right.$, $\left.3^{\circ} 55^{\prime} 51^{\prime \prime} \mathrm{E}\right)$ at ebb tide $1 \mathrm{~d}$ before the experiment started. The sediment sample was spread out on a tray, subsequently covered by 3 layers of lens tissue (What- man) and incubated overnight at an irradiance of $100 \mu \mathrm{mol} \mathrm{m} \mathrm{m}^{-2} \mathrm{~s}^{-1}$. The motile algae migrated through the tissue to the surface and were harvested by removing the upper layer of tissue. Subsequently, the algae were removed from the tissue by suspending them in growth medium, and kept a few hours at $15^{\circ} \mathrm{C}$ and $100 \mu \mathrm{mol} \mathrm{m} \mathrm{m}^{-2} \mathrm{~s}^{-1}$ until the experiment started.

Experimental set-up and EPS analyses. Culture: The cultures were subsampled in the early and late exponential, and early stationary phase (Days 3, 8 and 13, respectively). Before a sample of the algal suspension was taken, the culture was gently shaken until all cells were suspended, and subsequently the sand was allowed to settle. Samples $(n=3)$ were taken under aseptic conditions $1 \mathrm{~h}$ after the onset of light. The phenol-sulfuric acid assay (Dubois et al. 1956) was used to measure the content of extracellular polymeric substances, which mainly consisted of carbohydrates (Underwood et al. 1995). Glucose was used as a reference. Two different fractions of EPS were determined (Staats et al. 2000b): the fraction which was dissolved

Table 1. Composition of the artificial seawater medium for Cylindrotheca closterium

\begin{tabular}{|c|c|}
\hline Component & Concentration $\left(\mathrm{g} \mathrm{l}^{-1}\right)$ \\
\hline $\mathrm{NaCl}$ & 24.1 \\
\hline $\mathrm{Na}_{2} \mathrm{SO}_{4}$ & 32 \\
\hline $\mathrm{MgCl}_{2} \cdot 6 \mathrm{H}_{2} \mathrm{O}$ & 8.7 \\
\hline $\mathrm{KCl}$ & 0.54 \\
\hline $\mathrm{CaCl}_{2} \cdot 2 \mathrm{H}_{2} \mathrm{O}$ & 1.6 \\
\hline $\mathrm{NaHCO}_{3}$ & 0.18 \\
\hline $\mathrm{KBr}$ & 0.039 \\
\hline $\mathrm{NH}_{4} \mathrm{Cl}$ & 0.0268 \\
\hline $\mathrm{H}_{3} \mathrm{BO}_{3}$ & 0.011 \\
\hline $\mathrm{NaH}_{2} \mathrm{PO}_{4} \cdot \mathrm{H}_{2} \mathrm{O}$ & 0.0069 \\
\hline $\mathrm{SrCl}_{2} \cdot 6 \mathrm{H}_{2} \mathrm{O}$ & 0.010 \\
\hline $\mathrm{NaSi} \mathrm{O}_{3} \cdot 9 \mathrm{H}_{2} \mathrm{O}$ & 0.0426 \\
\hline $\mathrm{Na}_{2} \mathrm{Se} \mathrm{O}_{3} \cdot 5 \mathrm{H}_{2} \mathrm{O}$ & $1.6 \times 10^{-9}$ \\
\hline \multicolumn{2}{|l|}{ Citrate mix } \\
\hline $\mathrm{C}_{6} \mathrm{H}_{8} \mathrm{O}_{7} \cdot \mathrm{H}_{2} \mathrm{O}$ & 0.003 \\
\hline $\mathrm{Fe}-\mathrm{NH}_{4}$-citrate & 0.00036 \\
\hline \multicolumn{2}{|l|}{ Trace metal mix } \\
\hline $\mathrm{CuSO}_{4} \cdot 5 \mathrm{H}_{2} \mathrm{O}$ & $9.8 \times 10^{-6}$ \\
\hline $\mathrm{ZnSO}_{4} \cdot 7 \mathrm{H}_{2} \mathrm{O}$ & $22 \times 10^{-6}$ \\
\hline $\mathrm{CoCl}_{2} \cdot 6 \mathrm{H}_{2} \mathrm{O}$ & $10 \times 10^{-6}$ \\
\hline $\mathrm{MnCl}_{2} \cdot 4 \mathrm{H}_{2} \mathrm{O}$ & $18 \times 10^{-6}$ \\
\hline $\mathrm{Na}_{2} \mathrm{MoO}_{4} \cdot 4 \mathrm{H}_{2} \mathrm{O}$ & $6.3 \times 10^{-6}$ \\
\hline \multicolumn{2}{|l|}{ Vitamin mix } \\
\hline Biotin & $4 \times 10^{-8}$ \\
\hline Thiamine- $\mathrm{HCl}$ & $2 \times 10^{-5}$ \\
\hline Cyanocobalamin & $8 \times 10^{-7}$ \\
\hline Folic acid & $8 \times 10^{-8}$ \\
\hline Nicotinic acid & $4 \times 10^{-6}$ \\
\hline Thymine & $1.2 \times 10^{-4}$ \\
\hline Ca-d-pantothenate & $4 \times 10^{-6}$ \\
\hline Inositol & $2 \times 10^{-4}$ \\
\hline
\end{tabular}


in the medium was assigned as the colloidal material and was obtained after centrifuging the culture for 10 min at $5310 \times g$ (Sigma 4 K15 centrifuge). The other fraction (attached material) was closely bound to the cells and was extracted from the cell pellet by distilled water $\left(1 \mathrm{~h}, 30^{\circ} \mathrm{C}\right)$. To obtain the high molecular part of both fractions (termed colloidal and attached EPS in this study), cold $96 \%$ ethanol was added to the extracts to a final concentration of $75 \%$. During an overnight incubation at $-20^{\circ} \mathrm{C}$ the high molecular material precipitated. After centrifugation the pellet which contained the EPS was resuspended in distilled water and stored frozen at $-80^{\circ} \mathrm{C}$.

Field sample: Aliquots of $15 \mathrm{ml}$ of the algal suspension were transferred to scintillation vials and placed in a photosynthetron (Lewis \& Smith 1983) for incubation. To each sample $400 \mu \mathrm{l}$ of $\mathrm{NaH}^{14} \mathrm{CO}_{3}$ (final activity of $\left.10 \mu \mathrm{Ci} \mathrm{sample}{ }^{-1}\right)$ were added. The samples $(\mathrm{n}=2)$ were subsequently kept in the dark for $5 \mathrm{~min}$, prior to exposure to 9 different irradiances $(7,23,39,84,173$, $322,571,903$ and $1303 \mu \mathrm{mol}$ photons $\mathrm{m}^{-2} \mathrm{~s}^{-1}$; measured with a LI-COR quantum sensor Q19736 connected to a LI-1000 data logger) for $30 \mathrm{~min}$. During the incubation, temperature was kept constant at: (1) $10 \pm 1^{\circ} \mathrm{C}_{i}$ (2) $25 \pm$ $1^{\circ} \mathrm{C}$; and (3) $35 \pm 1{ }^{\circ} \mathrm{C}$. A dark (heterotrophic uptake) and poisoned ( $3 \%$ final concentration of glutaraldehyde; passive/abiotic uptake) control were taken. The incubation was stopped by adding glutaraldehyde (3\% final concentration). After the different fractionation steps (described below), the non-incorporated $\mathrm{C}$ was removed from the sample by adding $100 \mu \mathrm{l}$ of concentrated $\mathrm{HCl}$. Packard scintillation cocktail was added to each sample, and ${ }^{14} \mathrm{C}$ incorporation was measured with a Packard Tri-Carb 2300 TR scintillation counter, including quench correction. Dissolved inorganic $\mathrm{C}$ in the medium was determined by potentiometric titration of carbonate alkalinity (Parsons et al. 1984). The model of Walsby (1997) was used to calculate the efficiency of $\mathrm{C}$ fixation and EPS production at limiting light intensities $\left(\alpha^{\mathrm{B}}\right)$. The superscript ' $\mathrm{B}$ ' indicates that photosynthetic parameters are expressed per mg chl $a$.

Six fractions of $\mathrm{C}$ were determined: total fixed $C$, sum of intracellular, colloidal and attached extracellular C (Fraction 1); colloidal C (Fraction 2) and EPS (Fraction 3 ); attached C (Fraction 4) and EPS (Fraction 5); and intracellular $\mathrm{C}$ (Fraction 6). After the incubation with $\mathrm{NaH}^{14} \mathrm{CO}_{3}$ was terminated, the sample was centrifuged. The supernatant was divided into 2 subsamples. One of them contained the colloidal extracellular C (Fraction 2). To obtain the high molecular part of the colloidal C (EPS; Fraction 3) the second subsample was treated with ethanol as described above. The pellet containing the precipitated EPS was resuspended in distilled water. The cell pellet was extracted with distilled water $(1 \mathrm{~h}$, $30^{\circ} \mathrm{C}$ ). The sample was centrifuged, and the supernatant containing the attached extracellular $\mathrm{C}$ fraction was divided into 2 parts and treated as described above in order to obtain the attached $C$ (Fraction 4) and attached EPS fraction (Fraction 5). The remaining pellet was considered to represent intracellular C (Fraction 6).

Chl a analysis. Chl a was used as a measure of algal biomass. An aliquot of $15 \mathrm{ml}(\mathrm{n}=3)$ of the algal suspension was centrifuged for $10 \mathrm{~min}$ at $3500 \times g$ (Sigma $4 \mathrm{~K} 15$ centrifuge). Chl a was extracted from the pellet with $5 \mathrm{ml}$ of $96 \%$ acetone and measured with an Ultraspec 4000 spectrophotometer (Jeffrey \& Humphrey 1975).

Statistical analysis. To test whether the observed differences between the values obtained at the 3 studied temperatures $\left(10,25\right.$ and $\left.35^{\circ} \mathrm{C}\right)$ were statistically significant, the Sign test for not normally distributed data was performed using Statistica 5.1 software.

\section{RESULTS}

\section{Effect of temperature}

On Day 3 (exponential phase) the content of chl a of the cultures grown at temperatures between 4 and $35^{\circ} \mathrm{C}$ varied between 0.03 and $0.24 \mathrm{\mu g} \mathrm{ml}^{-1}$ (Fig. 1). The values of the sample grown at 4 and $10^{\circ} \mathrm{C}$ were much lower than those of the higher temperatures (14 and

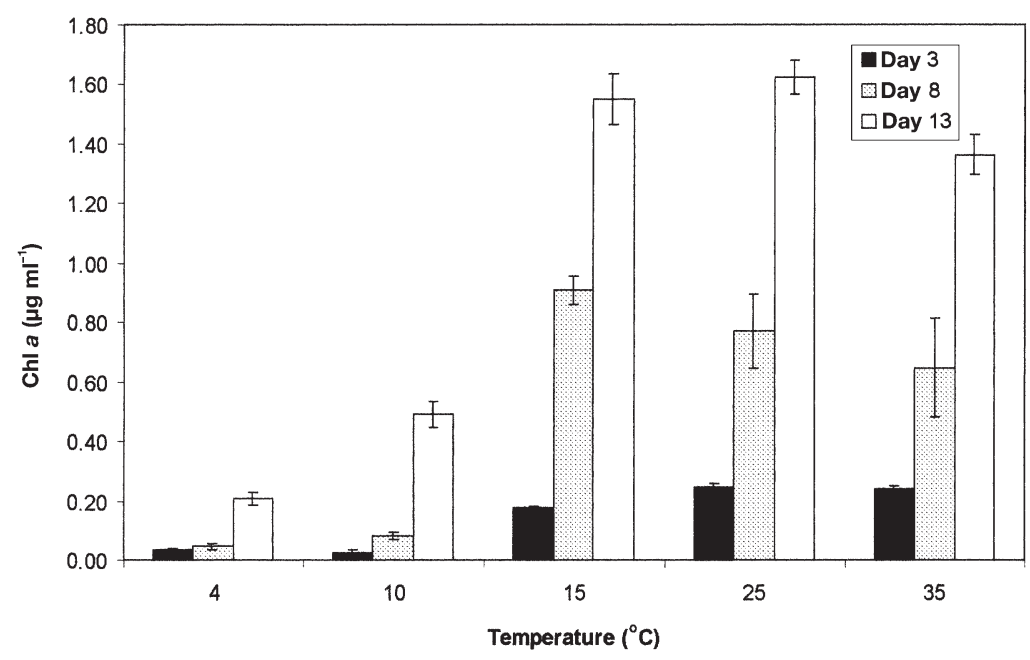

Fig. 1. Cylindrotheca closterium. Contents of chl $a$ at 5 different temperatures and 3 different days of a growth phase 

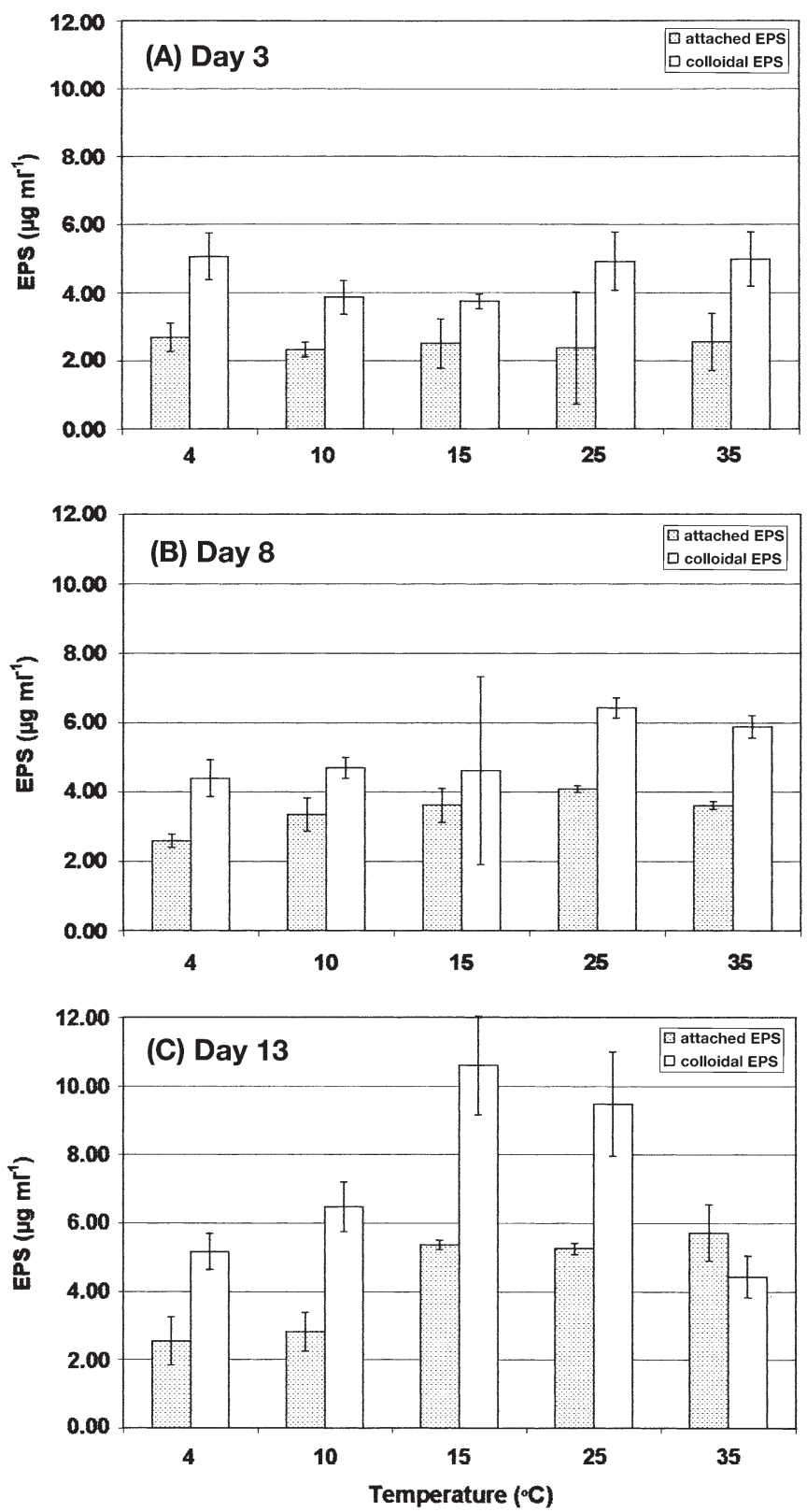

Fig. 2. Cylindrotheca closterium. Contents of attached and colloidal EPS at 5 different temperatures and at 3 different growth phases

$11 \%$ of the values measured at $25^{\circ} \mathrm{C}$, respectively). The effect of temperature became more evident at the end of the exponential phase of growth (Day 8): chl $a$ reached the highest value in the culture grown at $15^{\circ} \mathrm{C}$ $\left(0.91 \mu \mathrm{g} \mathrm{ml}^{-1}\right)$ and the lowest at $4^{\circ} \mathrm{C}\left(0.05 \mu \mathrm{g} \mathrm{ml}^{-1}\right)$. On Day 13 , chl a was lowest at $4^{\circ} \mathrm{C}\left(0.21 \mu \mathrm{g} \mathrm{ml}^{-1}\right)$ and highest values were measured at 15 and $25^{\circ} \mathrm{C}(1.55$ and $1.62 \mu \mathrm{g} \mathrm{ml}^{-1}$, respectively). Biomass showed in general a 9-fold increase $(8.9 \pm 5.11)$ from Days 3 to 13 . Algal growth rate, determined as the rate of increase in chl $a$, was highest at 4 and $10^{\circ} \mathrm{C}$ between Days 3 and $8(4.14$ and $3.35 \mathrm{~d}^{-1}$, respectively) compared to 0.36 to $0.4 \mathrm{~d}^{-1}$ at temperatures of 15 to $35^{\circ} \mathrm{C}$. Between Days 8 and 13, the growth rate of the cultures incubated at 4 and $10^{\circ} \mathrm{C}$ decreased to 1.55 and $0.73 \mathrm{~d}^{-1}$, respectively, and was even lower $\left(0.14\right.$ to $\left.0.17 \mathrm{~d}^{-1}\right)$ at temperatures of 15 to $35^{\circ} \mathrm{C}$.

At all temperatures, contents of colloidal EPS were invariably higher than attached EPS (Fig. 2). No clear difference in the mean values of attached and colloidal EPS over the range of temperatures investigated was observed on Day 3. On Day 8, temperature showed a slight effect on the production of EPS: the content of both EPS fractions increased slightly with increasing temperatures and reached a maximum at $25^{\circ} \mathrm{C}$. On Day 13, a clear effect of temperature was observed: the highest amount of EPS (sum of both fractions) was produced at 15 and $25^{\circ} \mathrm{C}$. Attached EPS was clearly lower at 4 and $10^{\circ} \mathrm{C}$ than at temperatures of $15^{\circ} \mathrm{C}$ and higher (only statistically significant with $\mathrm{p} \leq 0.05$ between 4 and $15^{\circ} \mathrm{C}$ ), but no visible differences were observed between 15,25 and $35^{\circ} \mathrm{C}$. The content of colloidal EPS had its highest value at $15^{\circ} \mathrm{C}$, followed by $25^{\circ} \mathrm{C}$. It was considerably lower at 4,10 and $35^{\circ} \mathrm{C}$. Statistically significant differences occurred between 4 and $10^{\circ} \mathrm{C}, 4$ and $25^{\circ} \mathrm{C}$, as well as 10 and $25^{\circ} \mathrm{C}$. The excreted material increased approximately 2 -fold between Days 3 and 13 (attached EPS: $1.75 \pm 0.62$, colloidal EPS: $1.67 \pm$ 0.79 ), much lower than the 9-fold increase of chl $a$ during the same period (see above).

The pattern of the figures changed when production of EPS was calculated per unit biomass, because chl a and EPS did not behave in the same manner during growth. In this case, the highest ratio ( $\mu$ g EPS [ $\mu$ g chl $a^{-1}$ ) was found at the 2 lowest temperatures (4 and $10^{\circ} \mathrm{C}$ ) on all days (Fig. 3). The ratios were highest on Day 3 and decreased with increasing age of the cultures at all temperatures. Decrease from Days 3 to 13 was highest at $4^{\circ} \mathrm{C}$ (from 76.42 to $12.24 \mu \mathrm{g}$ attached EPS [ $\mu \mathrm{g} \mathrm{chl} a^{-1}$ ] and 144.36 to $24.84 \mu \mathrm{g}$ colloidal EPS [ $\left.\mu \mathrm{g} \mathrm{ch} a^{-1}\right]$ ) and at $10^{\circ} \mathrm{C}$ (from 84.25 to $5.75 \mu \mathrm{g}$ attached EPS [ $\mu \mathrm{g} \mathrm{chl} a^{-1}$ ] and 139.67 to $13.18 \mu \mathrm{g}$ colloidal EPS $\left[\mu \mathrm{g}\right.$ chl $\left.a^{-1}\right]$ ). On Day 13, differences between $10^{\circ} \mathrm{C}$ and the higher temperatures became smaller in the attached EPS. The steep decrease between 10 and $15^{\circ} \mathrm{C}$ slowly disappeared. This was mainly due to the proportionally higher increase of biomass compared to the increase of the amount of EPS between Days 3 and 13.

\section{Effect of temperature and irradiance}

A short-term incubation experiment was conducted with a field sample of benthic diatoms. The effect of 
different irradiances and temperatures on photosynthetically fixed $\mathrm{C}$ and its partition in different intracellular and extracellular fractions was studied. To compare the values obtained at different temperatures, they were normalized to chl $a$, which was between 0.77 and $0.96 \mu \mathrm{g} \mathrm{ml}^{-1}$.

The results of this experiment are presented in Fig. 4. Values of each fraction are plotted in separate panels. Within all fractions (total $\mathrm{C}$, intracellular $\mathrm{C}$, colloidal C and EPS, and attached C and EPS) highest $\mathrm{chl}$ a specific rates of $\mathrm{C}$ incorporation were reached at a temperature of $25^{\circ} \mathrm{C}$ with only few exceptions. At irradiances which were higher than $571 \mu \mathrm{mol}$ photons $\mathrm{m}^{-2} \mathrm{~s}^{-1}$, lowest values were obtained at $10^{\circ} \mathrm{C}$, except in the case of attached C and EPS (Fig. 4D,F). Differences between the results measured at all 3 temperatures were statistically significant $(p \leq 0.05)$ for the fractions of total and attached C. Statistically different results were found between 25 and $35^{\circ} \mathrm{C}$ for the fractions of intracellular C, colloidal C and EPS. Values of attached EPS did not show statistically significant differences at all.

To better compare the differences between values measured at $25^{\circ} \mathrm{C}$ and those measured at the other temperatures, especially at the lower irradiances, the results are presented in another way (Fig. 5). Values obtained at 10 and $35^{\circ} \mathrm{C}$ were expressed as percentages of the mean value measured at $25^{\circ} \mathrm{C}$ which were, except for a few exceptions, maximal. At the lower irradiances (up to $571 \mu \mathrm{mol}$ photons $\mathrm{m}^{-2} \mathrm{~s}^{-1}$ ) differences between 10 and $25^{\circ} \mathrm{C}$ were less pronounced than those between 25 and $35^{\circ} \mathrm{C}$. Occasionally more colloidal $\mathrm{C}$ and EPS as well as attached EPS were produced at $10^{\circ} \mathrm{C}$. The temperature of $35^{\circ} \mathrm{C}$ resulted in lower production rates. This was true for all fractions, with the exception of attached C. At higher irradiances the pattern changed: differences between 25 and $35^{\circ} \mathrm{C}$ were smaller then those between 10 and $25^{\circ} \mathrm{C}$, with the exception of attached $\mathrm{C}$ and EPS. In addition, differences between the values obtained at 10 and $35^{\circ} \mathrm{C}$ became smaller at these high light intensities compared to those measured at lower irradiances. Highest differences between values measured at $25^{\circ} \mathrm{C}$ and those obtained both at 10 and $35^{\circ} \mathrm{C}$ occurred in the fraction of attached $\mathrm{C}$. The very high value measured at $10^{\circ} \mathrm{C}$ and $23 \mu \mathrm{mol}$ photons $\mathrm{m}^{-2}$ $\mathrm{s}^{-1}$ is probably a measuring error.

The calculation of the initial slope $(\alpha)$ of the fit of C fixation or EPS production versus irradiance gives an indication of the efficiency of these processes at limiting light intensities. In Table 2, the mean values and their standard deviation (SD) are shown. At $25^{\circ} \mathrm{C}$, efficiency
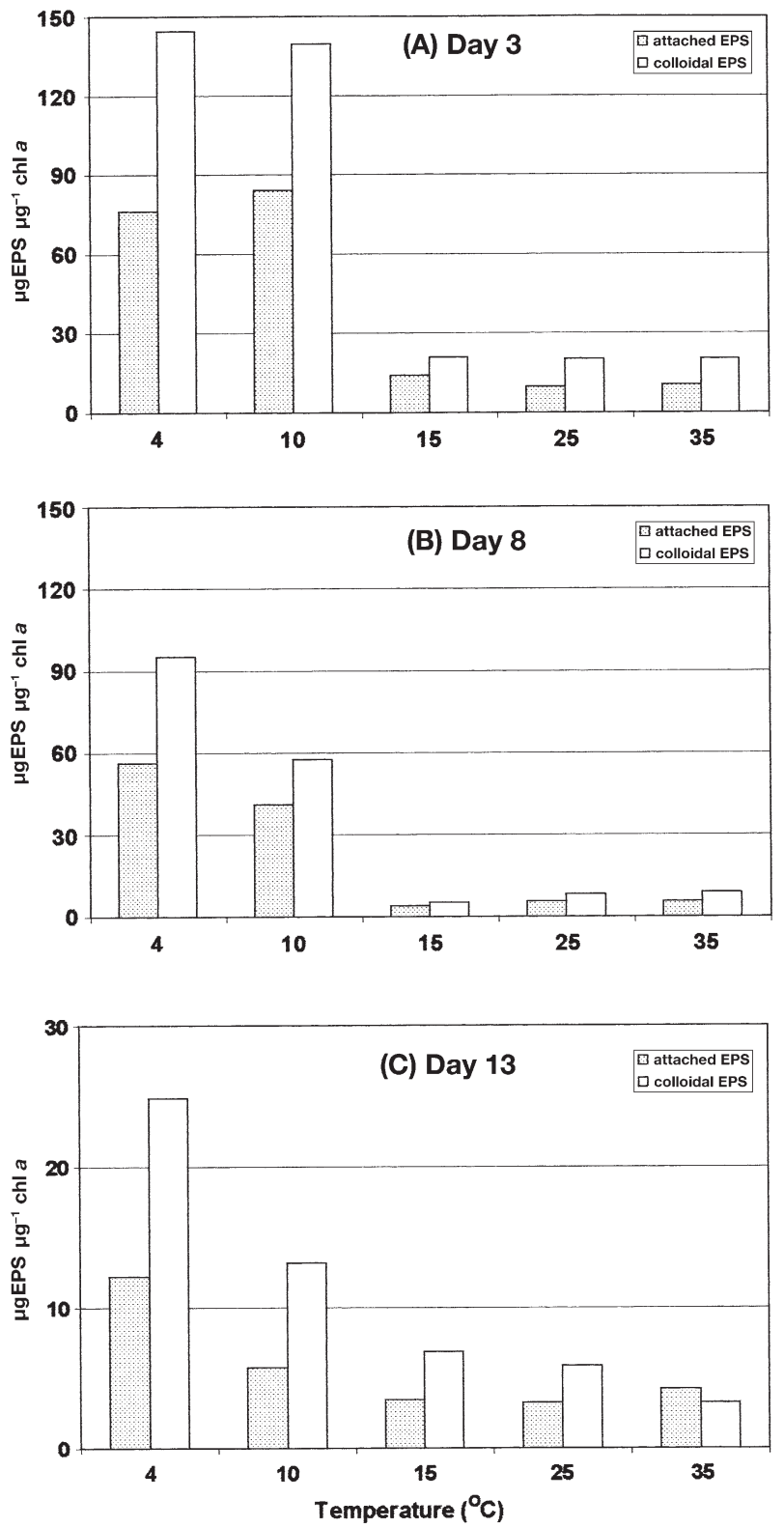

Fig. 3. Cylindrotheca closterium. Contents of attached and colloidal EPS normalized to chl $a$ at 5 different temperatures and at 3 different days of a growth phase

Table 2. Values of $\alpha^{\mathrm{B}}$ for $\mathrm{C}$ fixation or excretion at different irradiances and temperatures. $\alpha^{\mathrm{B}}$ is the photosynthetic efficiency normalized to chl a $\left(\mathrm{mgC} \mathrm{mg}^{-1}\right.$ $\operatorname{chl~} a^{-1} \mathrm{~h}^{-1}\left[\mu \mathrm{mol} \text { photons } \mathrm{m}^{-2} \mathrm{~s}^{-1}\right]^{-1}$ )

\begin{tabular}{|lccc|}
\hline & $10^{\circ} \mathrm{C}$ & $25^{\circ} \mathrm{C}$ & $35^{\circ} \mathrm{C}$ \\
\hline Total C & $0.0088 \pm 0.00009$ & $0.0101 \pm 0.0004$ & $0.0084 \pm 0.00011$ \\
Colloidal C & $0.0080 \pm 0.00004$ & $0.0079 \pm 0.0021$ & $0.0083 \pm 0.00021$ \\
Colloidal EPS & $0.0021 \pm 0.00010$ & $0.0021 \pm 0.0007$ & $0.0015 \pm 0.00002$ \\
Attached C & $0.0009 \pm 0.00064$ & $0.0025 \pm 0.0002$ & $0.0005 \pm 0.00004$ \\
Attached EPS & $0.0002 \pm 0.00002$ & $0.0002 \pm 0.0001$ & $0.0001 \pm 0.00002$ \\
Intracellular C & $0.0016 \pm 0.00030$ & $0.0023 \pm 0.0002$ & $0.0018 \pm 0.00036$ \\
\hline
\end{tabular}



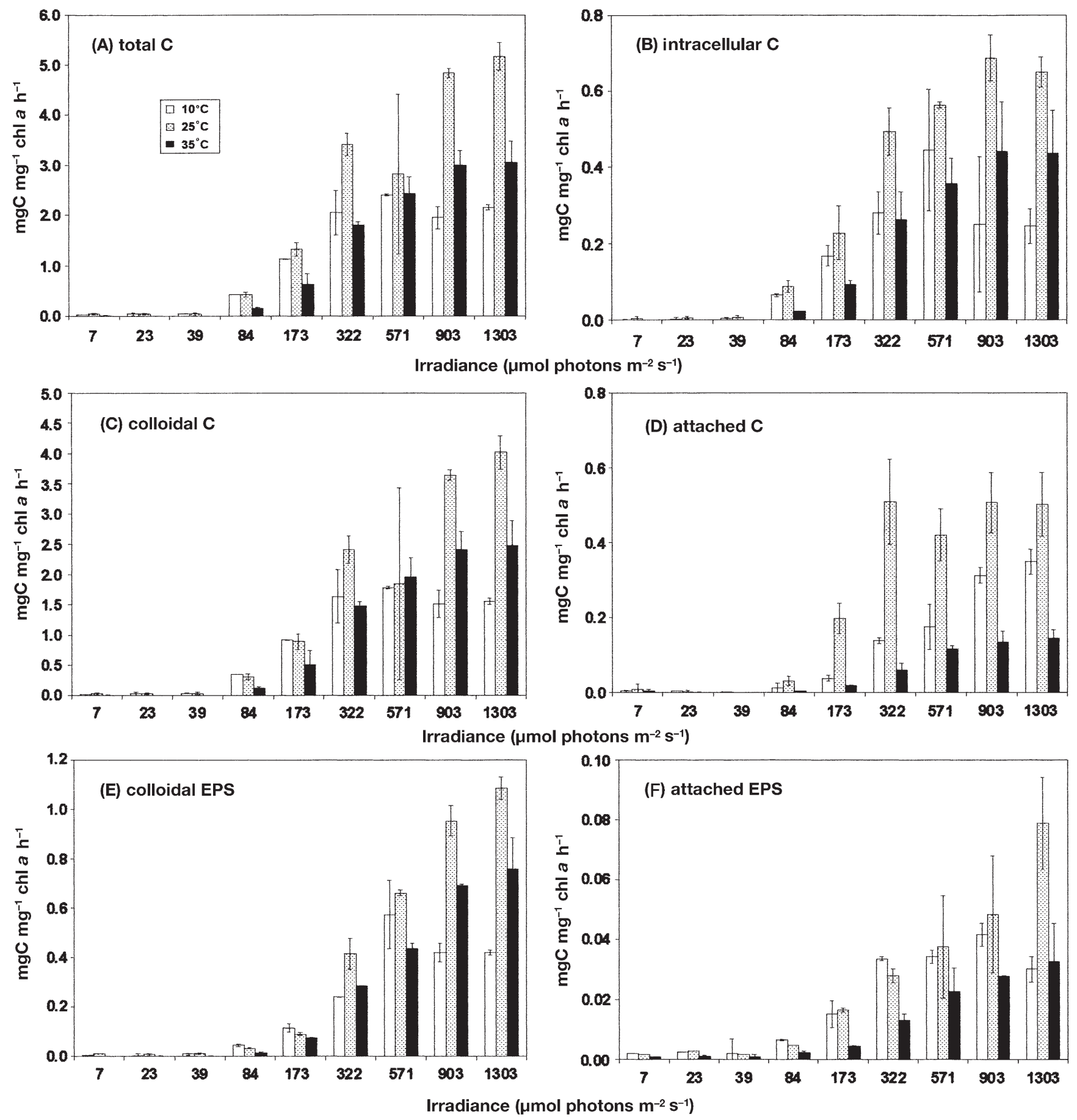

Fig. 4. Total $\mathrm{C}$ fixation and partitioning in fractions of intracellular $\mathrm{C}$, extracellular colloidal and attached $\mathrm{C}$, and extracellular col-loidal and attached EPS at different irradiances and temperatures by a field sample of benthic diatoms

was highest in the fractions of total $\mathrm{C}$, intracellular $\mathrm{C}$ and attached C. Temperature clearly had no influence on the efficiency of the production of colloidal $\mathrm{C}$ and attached and colloidal EPS, because the values hardly differed from each other.

\section{DISCUSSION}

Until now several aspects of the production of EPS - in the laboratory and the field-have been investigated (Underwood \& Paterson 1993, Goto et al. 

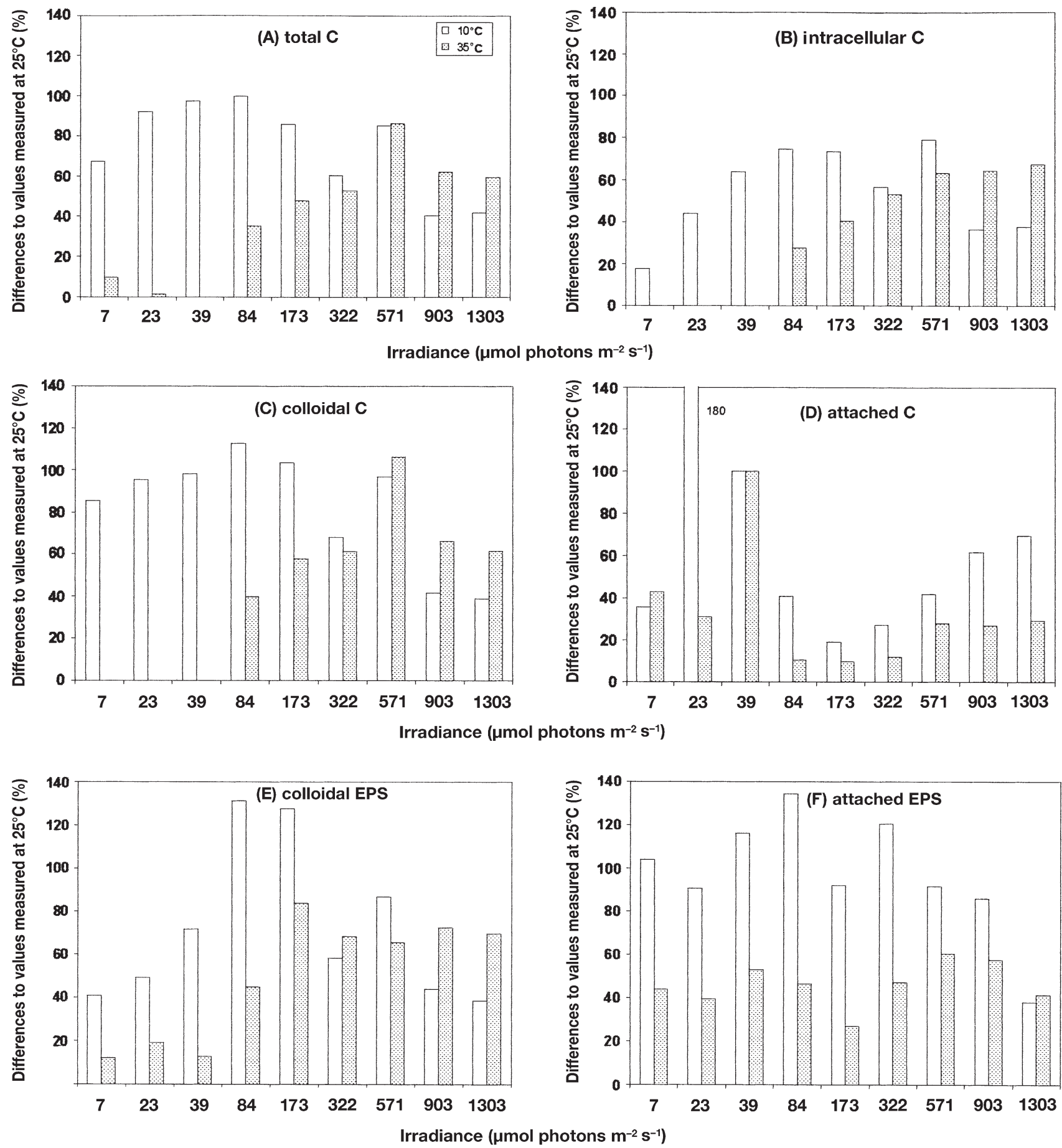

Fig. 5. Differences (in \%) between values of different $\mathrm{C}$ fractions measured at $25^{\circ} \mathrm{C}(=100 \%)$ and those measured at 10 and $35^{\circ} \mathrm{C}$ (obtained from a field sample of benthic diatoms)

1999, Staats et al. 2000a,b, Yallop et al. 2000), but hitherto the effect of temperature on EPS production in benthic diatoms is unknown. Temperature plays an important role in virtually all biological processes. However, it is difficult to measure the influence of temperature on EPS production in naturally occurring communities of diatoms because of the occurrence of other organisms that are involved in the cycle of EPS production and decomposition. Moreover, so far only standing stocks of exopolymers could be measured. 
Therefore, a set of experiments was performed in the laboratory using both a culture and a field sample of motile diatoms. First, the influence of different irradiances on the production of EPS in a culture and a field sample was carried out showing a direct relationship between the amount of irradiance provided and the quantity of excreted material (Wolfstein et al. unpubl.). That experiment was followed by those described here on the effect of temperature alone as well as the simultaneous influence of irradiance and temperature on the production of EPS. However, a direct comparison between the laboratory and field samples is difficult, because no information is available on the growth stage of the sample. It has been reported that microphytobenthic biomass in the field shows oscillations, i.e. an increase of biomass at good growth conditions (due to primary production at daytime exposure) and a decrease during the night (Blanchard et al. 2001). We assumed the algae had been in the exponential phase when the experiment started, because they were-after being separated from the sediment-kept under good growth conditions (suspended in fresh medium). In contrast to the culture of Cylindrotheca closterium, the field sample contained bacteria. Their contribution to EPS production or uptake (Decho 1990) was not studied here. However, we estimated that $5 \times 10^{5}$ bacterial cells ml ${ }^{-1}$ were present in the algal suspension. This is a low number compared to natural sediment, which may contain 6 to

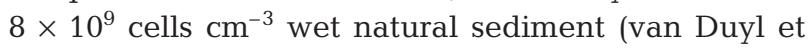
al. 1999) or $10^{9}$ bacteria $\mathrm{ml}^{-1}$ in pore water (Schmidt et al. 1998). Such a low number would have a negligible contribution to EPS production/consumption. Moreover, incubation time was kept short, which also minimized a possible effect of bacteria. For instance, Goto et al. (2001) reported that $2 \mathrm{~h}$ after the start of the experiment, $20 \%$ of the extracellular material of different fractions produced by natural benthic algae was degraded.

Both experiments showed a clear effect of temperature on the development of biomass (expressed as chl a) and the production of EPS on a long- and shortterm basis. In the first experiment, biomass of Cylindrotheca closterium was clearly and directly affected by temperature: the preferred temperature for growth was at 15 and $25^{\circ} \mathrm{C}$. This may be related to the fact that our stock culture was cultivated at $14^{\circ} \mathrm{C}$. Growth phase of the culture hardly influenced the pattern of chl a. However, the amount of EPS produced was affected by temperature as well as by growth phase. At the beginning of the experiment, a similar amount of EPS was observed at all temperatures. After $8 \mathrm{~d}$ of incubation, the highest production of EPS was measured at 15 and $25^{\circ} \mathrm{C}$. Attached EPS was less affected by temperature than colloidal EPS. The production of
EPS was indirectly affected by temperature through the amount of algal biomass that could produce EPS. When EPS production was expressed as $\mu \mathrm{gEPS}$ $\mu \mathrm{g} \mathrm{chl} a^{-1}$, production was highest at 4 and $10^{\circ} \mathrm{C}$. This result may be caused by the fact that very low chl $a$ content was present in the cultures grown at these temperatures compared to those grown at higher temperatures. Moreover, the results may also be influenced by the variation of chl $a$ cell $^{-1}$. The chl a content varies depending on the species and on the physiological state of the cells (de Jonge 1980, Davidson 1991). In our experiments, the chl a content cell ${ }^{-1}$ increased with increasing age of the cultures over the range of temperatures studied. The chl a content cell $^{-1}$ was 2 to 14 times higher in the cultures grown at temperatures of $15^{\circ} \mathrm{C}$ and higher compared to the cultures grown at 4 and $10^{\circ} \mathrm{C}$. This observation is in agreement with Geider (1987), and the lower chl a content at lower temperatures is due to photosynthetic adjustment that decreases the probability of light absorption (Maxwell et al. 1994).

The results obtained can further be explained by assuming overflow metabolism occurring at low temperatures. At low temperature, cells did not grow as fast as at higher temperatures, and the photosynthetically fixed C was transferred to EPS, especially to colloidal EPS. Biomass-normalized EPS production became smaller with increasing age of the culture, which was also observed by Underwood \& Smith (1998), and differences between the temperatures became smaller as well. The production of EPS is closely linked to photosynthesis (Smith \& Underwood 2000, Wolfstein et al. unpubl.). The culture might have become lightlimited when its biomass increased. The amount of photosynthetically fixed $\mathrm{C}$ and therefore the amount of excreted material decreased. Nutrient limitation was unlikely because the content of chl a continued to increase until Day 13.

In conclusion, this work emphasizes the importance of: (1) how the data are expressed (absolute values or biomass-normalized); and (2) growth phase of the algae. Both these factors largely determine the conclusions that will be drawn. It is of further importance as to whether the results are normalized to cell counts, $\mathrm{chl} a$ or protein, because EPS production related to different biomass parameters did not necessarily give the same pattern (Smith \& Underwood 2000).

The short-term experiment with the field sample was conducted in order to provide an answer on the effects of temperature and light on EPS production. In addition, this experiment yielded production rates rather than standing stock amounts of EPS as in the first experiment. A maximum rate of $\mathrm{C}$ fixation and excretion was found at $25^{\circ} \mathrm{C}$, confirming the results of Colijn \& van Buurt (1975) and those of Blanchard et al. (1996), 
who reported a maximum level of photosynthesis between 20 and $25^{\circ} \mathrm{C}$. A close relationship between the process of photosynthesis and EPS production was reported by Smith \& Underwood (2000) and Wolfstein et al. (unpubl.). Our experiment further showed an effect of temperature on the fractions of total C, intracellular $\mathrm{C}$ and attached $\mathrm{C}$ in the light-limited part of the P/E curve (highest fixation/production efficiency at $25^{\circ} \mathrm{C}$ ). This disagrees with the fact that the effect of short-term changes in temperature on the initial slope of a P/E curve is relatively minor (Mortain-Bertrand et al. 1988, Falkowski \& Raven 1997). In all fractions, highest production rates were normally measured at $25^{\circ} \mathrm{C}$, followed by those obtained at $10^{\circ} \mathrm{C}$. At low irradiances, the temperature of $35^{\circ} \mathrm{C}$ resulted in lower production rates, but results were not always statistically significant. In the first experiment, in which the algae were incubated at $100 \mu \mathrm{mol}$ photons $\mathrm{m}^{-2} \mathrm{~s}^{-1}$, results obtained at this temperature were also lower compared to those measured at $10^{\circ} \mathrm{C}$. At lower irradiances, the temperature of $35^{\circ} \mathrm{C}$ had an inhibitory effect on the production rates of all fractions.

The fractions of attached and colloidal EPS differed from each other both in quantity and pattern related to temperature and light suggesting that each type of EPS has a different function. From the experiment with the culture, colloidal EPS was most likely the result of an overflow mechanism and was therefore more affected by temperature than attached EPS. Additionally, in the field sample, the production of this type of EPS was less influenced by temperature than colloidal EPS. Perhaps this observation should be taken as evidence that attached EPS is more important for motility. Motility should be independent of temperature, because migration (stepwise coloring of the sediment surface during emersion of tidal mudflats) was observed at all seasons and at temperatures between 5 and $35^{\circ} \mathrm{C}$ (pers. obs.). Unfortunately, to our knowledge no reports have been published about migration velocity at different temperatures. On the other hand, Ruddy et al. (1998) suggested that colloidal EPS may be produced for the purpose of migration in order to improve growth conditions, i.e. increase nutrient availability. According to J. F. C. de Brouwer (pers. comm.) attached EPS is probably a reserve product and can be mobilized in the dark. Hence, for the time being we cannot offer a fully satisfying explanation for the function of either type of EPS.

Acknowledgements. We would like to thank Jan Peene for technical assistance, and Jody de Brouwer and Jacco Kromkamp for valuable comments on the manuscript. This work was financially supported by the European project MAS-CT98-0166-Climerod. This is publication 2928 of the Netherlands Institute of Ecology (NIOO-KNAW).

\section{LITERATURE CITED}

Barranguet C, Kromkamp J, Peene J (1998) Factors controlling primary production and photosynthetic characteristics of intertidal microphytobenthos. Mar Ecol Prog Ser 173:117-126

Blanchard GF, Guarini JM, Richard P, Gros PH, Mornet F (1996) Quantifying the short-term temperature effect on light-saturated photosynthesis of intertidal microphytobenthos. Mar Ecol Prog Ser 134:309-313

Blanchard GF, Guarini JM, Orvain F, Sauriau PG (2001) Dynamic behaviour of benthic microalgal biomass in intertidal mudflats. J Exp Mar Biol Ecol 264:85-100

Colijn F, van Buurt G (1975) Influence of light and temperature on the photosynthetic rate of marine benthic diatoms. Mar Biol 31:209-214

Davidson IR (1991) Environmental effects on algal photosynthesis: temperature. J Phycol 27:2-8

Decho AW (1990) Microbial exopolymer secretions in ocean environments: their role(s) in food webs and marine processes. Oceanogr Mar Biol Annu Rev 28:73-153

De Jonge VN (1980) Fluctuations in the organic carbon to chlorophyll-a ratios for estuarine benthic diatom populations. Mar Ecol Prog Ser 2:345-353

Dubois M, Gilles KA, Hamilton JK, Rebers PA, Smith F (1956) Colorimetric method of determination of sugars and related substances. Anal Chem 18:350-356

Falkowski PG, Raven JA (1997) Photosynthesis in continuous light. In: Falkowski PG, Raven JA (eds) Aquatic photosynthesis. Blackwell Scientific Publications, Oxford, p 193-227

Geider RJ (1987) Light and temperature dependence of the carbon to chl a ratio in microalgae and cyanobacteria: implications for physiology and growth of phytoplankton. New Phytol 106:1-34

Goto N, Kawamura T, Mitamura O, Terai H (1999) Importance of extracellular organic carbon production in the total primary production by tidal-flat diatoms in comparison to phytoplankton. Mar Ecol Prog Ser 190:289-295

Goto N, Mitamura O, Terai H (2001) Biodegradation of photosynthetically produced extracellular organic carbon from intertidal benthic algae. J Exp Mar Biol Ecol 257:73-86

Hoagland KD, Rosowski JR, Gretz MR, Roemer SC (1993) Diatom extracellular polymeric substances: function, fine structure, chemistry and physiology. J Phycol 29:537-566

Jeffrey SW, Humphrey GF (1975) New spectrophotometric equation for determining chlorophylls $a, b, c_{1}$ and $c_{2}$ in higher plants, algae and natural phytoplankton. Biochem Physiol Pflanz 167:191-194

Lewis MR, Smith JC (1983) A small volume, short-incubation time method for measurement of photosynthesis as a function of incident irradiance. Mar Ecol Prog Ser 13:99-102

Maxwell DP, Falk S, Trick CG, Huner NP (1994) Growth at low temperature mimics high-light-acclimation in Chlorella vulgaris. Plant Physiol 105:535-543

Mortain-Bertrand A, Descolas-Gros C, Jupin H (1988) Growth, photosynthesis and carbon metabolism in the temperate marine diatom Skeletonema costatum adapted to low temperature and low photo-flux density. Mar Biol 100:135-141

Parsons TR, Maita Y, Lalli CM (1984) A manual of chemical and biological methods for seawater analysis. Pergamon Press, Oxford

Paterson DM (1989) Short-term changes in the erodibility of intertidal cohesive sediments related to the migratory behavior of epipelic diatoms. Limnol Oceanogr 34: $223-234$ 
Ruddy G, Turley CM, Jones TER (1998) Ecological interaction and sediment transport on an intertidal mudflat. II. An experimental dynamic model of the sediment-water interface. In: Black KS, Paterson DM, Cramp A (eds) Sedimentary processes in the intertidal zone. Geological Society, London, p 149-166

Schmidt JL, Deming JW, Jumars PA, Keil RG (1998) Constancy of bacterial abundance in surficial marine sediments. Limnol Oceanogr 43:976-982

Smith DJ, Underwood GJC (1998) Exopolymer production by intertidal epipelic diatoms. Limnol Oceanogr 43: 1578-1591

Smith DJ, Underwood GJC (2000) The production of extracellular carbohydrates by estuarine benthic diatoms: the effect of growth phase and light and dark treatment. J Phycol 36:321-333

Staats N, Stal LJ, Mur LR (2000a) Exopolysaccharide production by the epipelic diatom Cylindrotheca closterium: effects of nutrient conditions. J Exp Mar Biol Ecol 249: $13-27$

Staats N, Stal LJ, de Winder B, Mur LR (2000b) Oxygenic photosynthesis as driving process in exopolysaccharide production of benthic diatoms. Mar Ecol Prog Ser 193: 261-269

Editorial responsibility: Otto Kinne (Editor), Oldendorf/Luhe, Germany
Sutherland TF, Grant J, Amos CL (1998) The effect of carbohydrate production by the diatom Nitzschia curvelineata on the erodibility of sediment. Limnol Oceanogr 43:65-72

Underwood GJC, Paterson DM (1993) Seasonal changes in diatom biomass, sediment stability and biogenic stabilization in the Severn estuary. J Mar Biol Assoc UK 73: $871-887$

Underwood GJC, Smith DJ (1998) Predicting epipelic diatom exopolymer concentrations in intertidal sediments from sediment chlorophyll a. Microb Ecol 35:116-125

Underwood GJC, Paterson DM, Parkes RJ (1995) The measurement of microbial carbohydrate exopolymers from intertidal sediments. Limnol Oceanogr 40:1243-1253

van Duyl FC, de Winder B, Kop AJ, Wollenzien UIA (1999) Tidal coupling between carbohydrate concentrations and bacterial activities in diatom-inhabited intertidal mudflats. Mar Ecol Prog Ser 191:19-32

Walsby AE (1997) Numerical integration of phytoplankton photosynthesis through time and depth in a water column. New Phytol 136:189-209

Yallop ML, Paterson DM, Wellsbury P (2000) Interrelationships between rates of microbial production, exopolymer production, microbial biomass, and sediment stability in biofilms of intertidal sediments. Microb Ecol 39:116-127

Submitted: August 1, 2001; Accepted: January 31, 2002 Proofs received from author(s): June 6, 2002 